\title{
An Environmental Sampling Program for a Solar Evaporation Pond for Liquid Radioactive Wastes
}

¿

$\stackrel{7}{\infty}$

$\stackrel{\text { D }}{\frac{2}{5}}$ 


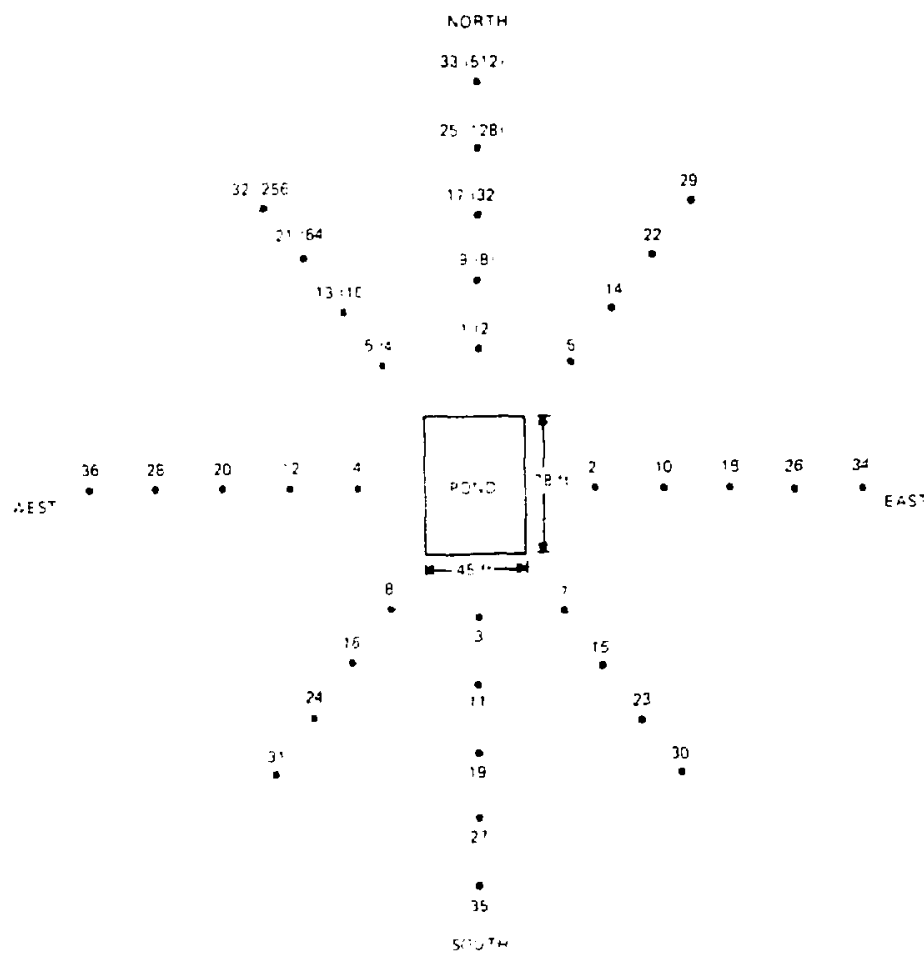

Fig. 2.

Sisil sampling grid (not to scale) used in the determination of initiai radioactivity levels at the liquid radinactice waste solar ecaporation pond site. The number in parentheses following the sample number is the distance (in feet) of the sampling site li, m a side or corner of the pond.

then allowed to drop by some amount; after equilibration in the bell jar (to distribute the moisture uniformly through the soil), the resistance and mass were measured again. This cycle of drying, equilibration, and resistance and mass measurement was repeated until the soil was dry.

A mathematical relationship between the cell resistance $x$ and the percent soil moist ure $y$ was established by regression analysis. The data were fitted to four regression models ${ }^{7}$ to determine which model best fits the data, as indicated by the value of the correlation coefficient $r$. The four models and the corresponding correlation coefficients are listed in Table II.
The power curve

$y=2162 x^{0.592}$

or equivalently.

$\log y=3.33-0.532 \log x$

fits the data best. This calibration curve and the experimental data were plotted (see Fig. 3) using MAPPER $^{8}$ (a computer graphics package). Given any soil cell resistance reading, the percent soil moisture can be determined easily. 
TABLE I

\section{RADIOACTIVITY LEVELS OF SOIL SAMPLES}

\begin{tabular}{|c|c|c|}
\hline $\begin{array}{c}\text { Sample } \\
\text { No. }\end{array}$ & $\begin{array}{c}\text { Alpha } \\
\text { Activitye }\end{array}$ & $\begin{array}{c}\text { Beta } \\
\text { Activity }\end{array}$ \\
\hline 1 & 39 & 299 \\
\hline 2 & 43 & 291 \\
\hline 3 & 38 & 300 \\
\hline 4 & 49 & 310 \\
\hline 5 & 45 & 287 \\
\hline 6 & 38 & 266 \\
\hline 7 & 47 & 274 \\
\hline 8 & 29 & 287 \\
\hline 9 & 36 & 262 \\
\hline 10 & 44 & 248 \\
\hline 11 & 43 & 294 \\
\hline 12 & 35 & 301 \\
\hline 13 & 42 & 303 \\
\hline 14 & 49 & 287 \\
\hline 15 & 48 & 292 \\
\hline 16 & 34 & 285 \\
\hline 17 & 48 & 271 \\
\hline 18 & 46 & 279 \\
\hline 19 & 47 & 301 \\
\hline 20 & 42 & 261 \\
\hline 21 & 26 & 251 \\
\hline 22 & 41 & 284 \\
\hline 23 & 49 & 255 \\
\hline 24 & 33 & 259 \\
\hline 25 & 36 & 276 \\
\hline 26 & 28 & 287 \\
\hline 27 & 33 & 280 \\
\hline 28 & 49 & 264 \\
\hline 29 & 45 & 237 \\
\hline 30 & 33 & 284 \\
\hline 31 & 47 & 256 \\
\hline 32 & 48 & 269 \\
\hline 33 & 39 & 261 \\
\hline 34 & 50 & 284 \\
\hline 35 & 44 & 293 \\
\hline 36 & 41 & 257 \\
\hline
\end{tabular}

- Measured with probe PN288185.

Measured with probe PN252455.
TABLE II

REGRESSION ANALYSIS RESULTS

\begin{tabular}{|c|c|c|}
\hline $\begin{array}{c}\text { Regression } \\
\text { Analysis } \\
\text { Model }\end{array}$ & Curve Equation & $\begin{array}{c}\text { Correlation } \\
\text { Coefficient } \\
\end{array}$ \\
\hline Power & $y=b x^{m}$ & -0.99 \\
\hline Exponential & $y=b e^{m x}$ & -0.97 \\
\hline Logarithmic & $y=b+m \ln x$ & -0.84 \\
\hline Iinear & $y=b+m x$ & -0.77 \\
\hline
\end{tabular}

Before the pond was filled, 12 calibrated soil cells were huried under the liner around the sides and at the bottom of the pond (see Fig. 4). The soil cell resist ance and temperature values were deternined when the pond was filled (see Table III); subsequent values will detect leaks in the liner.

\section{B. Air Monitoring}

Four Paxton air pumps. * installed nne on each side of the pond, collect representative samples of airborne particuletes. Each pump can pull approximately $0.165 \mathrm{~m}^{3} / \mathrm{s}(350 \mathrm{cfm})$ through a Microsorban filter medium with a total sampling surface of 0.232 $\mathrm{m}^{2}\left(360 \mathrm{in}^{2}\right)$. The filters rest on a pleated filter holder of stainless steel wire cloth.

The pumps are at ground level adjacent to the banks and are housed in weather-tight units. The filter heads are attached to snorkels that rise above the pond banks. Initially, the filters will be analyzed for gross alpha and beta activity; analysis for particular radioisotnpes such as ${ }^{23 a} \mathrm{Pu},{ }^{230} \mathrm{Pu},{ }^{2 * 1} \mathrm{Am}$. ${ }^{137} \mathrm{Cs}$, and ${ }^{90} \mathrm{Sr}$ is possible. The filters will be analyzed at a frequency such that a particulate mass sufficien $̂$ for accurate analysis is accumulated.

The pumps have been modified to sample at ground level if desired. They also may be rotated to

- Manufactured hy Paxton Products Inc., 929 Olympic Blvd., Santa Monica, CA 90404. 


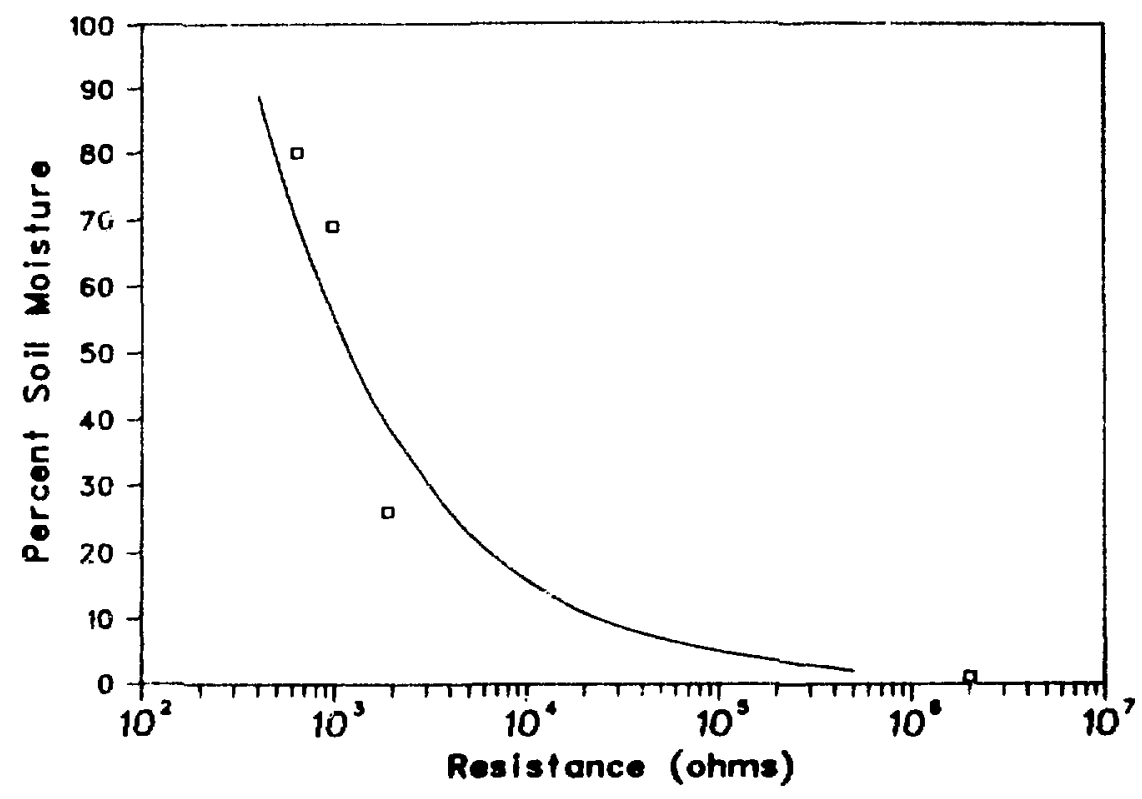

fig. is.

Calibration :urle for the soul colls used to detect leaks in the solar evaporation pond liner. The squares are experimental dala; the solid line is the curle determined to be the best fit to the dala.

sample in the direction of prevailing winds. At pre. sent, the pumps sample above the pond banks in the four major compass directions.

\section{Vegetation Sampling}

Representative samples of the most common vegetation at the site were collected before construction using a sampling grid surrounding the pond. Listed below are the common names and the genusspecies names of the vegetation sampled.

- Blue grama grass (Bouteloua gracilis)

- Indian paintbrush (Castilleja integra)

- Chamisa (Chrysothamnus nauseosus)

- Big sagebrush (Artemisia tridentata)

- Gambel oak (Quercus gambelii)

- Birchleaf mountain mahogany (Cercocarpus montanus)
- One-seed juniper (Juniperus monosperma)

- P'inon pine (Pinus edulis)

- Ponderosa pine (Pinus ponderosa)

These samples are heing analyzed for gross alpha and beta contaminants and for tritium to establish background levels for comparison with results from samples collected when the pond is operative. The samples will be stored so that other analyses can be made at a future date.

\section{Meteorological Data Collection}

A portable weather station* installed at the site collects meteorological data. Wind direction and

- Manufictured by Metenrology Research. Inc., 464 W. Wood. bary Rd. Altadena, CA $91(0) 1$. 


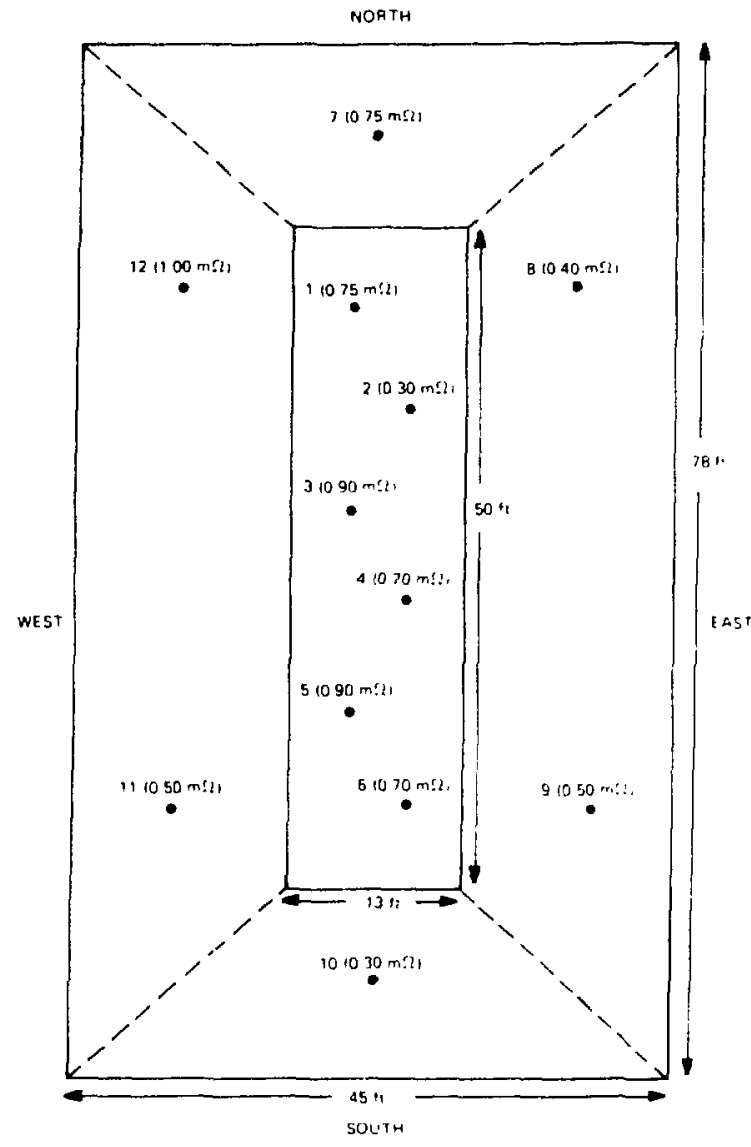

Fig. 4.

Locations and resistances of the soil cells used to detect leaks in the liner of the liquid radioac. tive waste solar evaporation pond. The resistances are those measured before the pond was filled.

speed, air temperature, and precipitation are measured with an accuracy of $\pm 2 \%$ and are recorded on a spring-driven strip chart recorder. The station, housed in a weather-tight unit, can operate for 120 days on battery power and can be mounted on an extendable tripod or a solid pipe. The unit is located on the southwestern bank of the pond away from wind-disturbing obstructions.

Meteorological data will be gathered on a routine basis and analyzed to determine whether a correlation exists between weather conditions and results from air, vegetation, and soil sampling.
TABLE III

\section{INITIAL SOIL CELL RESISTANCE AND TEMPERATURE VALUES"}

\begin{tabular}{|c|c|c|}
\hline $\begin{array}{l}\text { Soil } \\
\text { Cell } \\
\text { No. }\end{array}$ & $\begin{array}{c}\text { Resistance } \\
(M \Omega) \\
\end{array}$ & $\begin{array}{c}\text { Temperature } \\
\left({ }^{\circ} \mathbf{F}\right)\end{array}$ \\
\hline 1 & 0.75 & 70 \\
\hline 2 & 0.30 & 72 \\
\hline 3 & 0.90 & 70 \\
\hline 4 & 0.70 & 70 \\
\hline 5 & 0.90 & 72 \\
\hline h & 0.70 & 70 \\
\hline 7 & 1.00 & 72 \\
\hline 8 & 0.40 & 70 \\
\hline 9 & 0.50 & 70 \\
\hline 101 & 0.30 & 72 \\
\hline 11 & 0.50 & 70 \\
\hline 12 & $1 .(k)$ & 74 \\
\hline
\end{tabular}

\section{E. Biological Vector Control}

Aquatic and terrestial biological vectors for the export of radioactivity from the pond will be studied. Aquatic vectors include algae, aquatic insects and gastropods, and organic floc generated by decomposing plant material. Terrestial vectors include birds (particularly waterfowl), mammals, and insects.

If observations indicate that small wildlife are gaining access to the pond, several options to repel them will be explored. Commercial sonic devices, such as those used in orchards, can be installed to keep rodents and birds away. Electronic insect traps can be installed around the pond banks. If necessary, an algicide can be used to suppress algae growth. Nets can be secured over the pond to prevent waterfowl (especially bottom-feeders such as coots) from landin in on its surface. Studies indicate that ducks feed most heavily on the organically rich floc covering pond sediments." This floc also contains most of the contaminants. 


\section{F. Photographic Survey}

A photographic survey of the pilot pond was carried out during comstruction to document how the pond was built and how the surrounding environment was disturbed. Another survey will be taken during the operationsl phase.

\section{SUMMARY}

A pilot pond for solar evaporation of liquid raclinactive wastes has been constructed at LASL to address two problems. The first concerns the economy and suitability of solar evaporation com pared with, for instance, an evaporator fïred by fossil fuels. The ot her. and more important. problem is whether such a pond can be controlled and monitored in a manner that prevents escape of radioactivity to the enviromment. T'u attack the lattor problem, we have designed an envirmmental sampling program o detect the transport of radinactivity to the soil, air, and vegetation in the vicinity of the pond and are studying measures $t$ control the expret of radioactivity by biological vectors.

\section{REFERENCFS}

1. T. E. Hakonsom, J. W. Nyhan, and W. D. Burtymum, "Accumulation and Transport of Sisl Plutoniam in Liquid Waste Discharge Areas at Los Alamos," Transuranium Nuclides Environ.. Proc. Symp. San Francisco, California, Vovember 17-21, 1975 (International Ainic Finergy Agency, Vienna. 1976). pp. 175-189.
2. F. Terry Rees, I. M. Cleveland, and W. C. Gottschall. "Dispersion of Plutonium from Contaminated Pond Sediments." Environ. Sci. Technol. 121085 (1978).

3. Richard M. Finery, Donald C. Klopfer, and M. colleen Mcshane. "The Ecological Export of Plutonim from a Reprocessing Waste Pond," Health lhys. $34255-269$ (1978).

4. ('. .). Imbarger and M. A. Wolf, "A Battery Operated Portable Phoswich Detector for Field Monitoring of Low Levels of Transuranic Contaminants." Nucl. Iustrum. Methods 155453 $457(1978)$.

5. M. A. Hilli, "Portable Survey Instrument for Low levels of Transuranic Contaminants," Los Namos Scientific laboratory report LA-6860MS (buty jigh).

6. Sinil Motiture-Temperature Meter and Soil (rolls (Soiltert. Inc. Evanston. Illinois, 1975).

i. Applied itatistics (Texas Instruments, Inc., Dallas. Texas. 1977.

8. D. A. Wahl, "Mapper: High Quality Illustrations for Presentations and Reports," Los Alamos Scientific Laboratory Program Library write-up I. A.J (March 1979).

9. B. F. Vaughan, "Ecological Distribution and Fate of llutonium and Americium in a Processing Waste Pond on the Hanford Reservation," Battelle - Pacific Northwest Laboratories annual report BNWL.2(0)!, P'T2 (1976). 